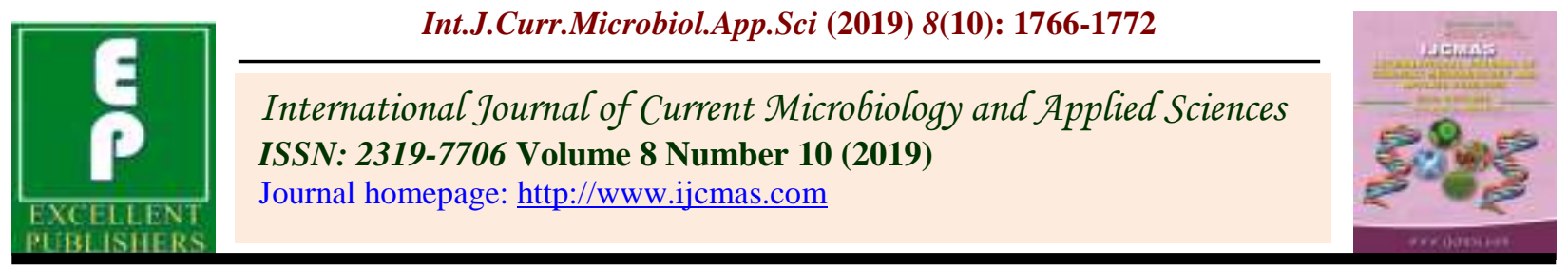

Original Research Article https://doi.org/10.20546/ijcmas.2019.810.205

\title{
Integrated Blast Disease Management of Paddy in Hill Zone of Karnataka, India
}

\author{
G. N. Hosagoudar* \\ Junior Rice Pathologist, AICRIP on Rice, Agricultural and Horticultural Research Station, \\ Ponnampet, Kodagu-571216, Karnataka, India \\ *Corresponding author
}

\section{A B S T R A C T}

Keywords

Blast, Disease,

Integrated,

Management and

Paddy

\section{Article Info}

Accepted:

15 September 2019

Available Online:

10 October 2019
Rice (Oryza sativa L.) is an important cereal crop belonging to the grass family Poaceae. An experiment was conducted during Kharif 2017 and 2018 to know the impact of six integrated disease management treatments. Among six treatments, Treatment Number-6 (N1: Incorporation of FYM @ $1 \mathrm{~kg} / \mathrm{m}^{2}$ in the nursery + N2: Seed treatment with carbendazim $(2 \mathrm{~g} / \mathrm{kg})+\mathrm{N} 3$ : Apply DAP @ $108 \mathrm{~g} / 10 \mathrm{~m}^{2}$ nursery area before sowing the seeds + M5: Application of FYM during land preparation before transplanting (@ $\left.1 \mathrm{~kg} / \mathrm{m}^{2}\right)+$ Trichoderma formulation $(2 \mathrm{~g} / \mathrm{kg}$ of FYM) + M6 : Cultural practices (cleaning of bunds i.e. no weeds/infected straw on bunds and main field) + M8: 75\% RDF (N:P:K: Zn-67.50:56.25:56.25:15) + micronutrient solution@2 $\mathrm{g}$ or $2 \mathrm{ml}$ micronutrient product/litre of water, Micronutrient should be sprayed 15-20 days after transplanting. Micronutrient application should be repeated after 15 days after the first application + M9: One blanket application of granular insecticide (fipronil) at 15 DAT + M10: Need based application of following fungicides (tricyclazole 75 WP @ $0.6 \mathrm{~g} / \mathrm{l}$ ) based on the disease) with least pooled leaf blast disease index of $20.15 \%$ and neck blast disease incidence of $15.73 \%$ respectively. Further, the highest pooled yield was recorded in the same Treatment Number-6 (4359.26kg/ha).

\section{Introduction}

Rice (Oryza sativa L.) is the most important cereal crop of the world. Asia known as rice bowl of the world as 90 per cent or more of the world's rice is grown and consumed in Asia. Among the Asian countries, India is one of the leading producers of rice (1). Starting in 2500 B.C. rice has been a source of food for people. Rice production originated in China, and was spread to countries such as Sri Lanka and India. It is believed that rice was brought to West Asia and Greece in 300 B.C. by Alexander the Great's armies.

China and India account for roughly 50 per cent of the world's total rice area and jointly produce 55 per cent of world's rice. Other 
major rice-growing countries are Indonesia, Bangladesh, Vietnam, and Thailand, which produce respectively nine, six, five, and four percent of world's rice.

Projection of India rice production target for 2025 AD is 140 million tons, which can be achieved only by increasing the rice production by over 2 million tons per year in the coming decade and this has to be achieved against back drop of diminishing natural resource such as land and water.

Globally, rice is cultivated with an area about 161.4 million hectare, production of about 633.3 million tonnes with a productivity of 3.14 tonnes per hectare (2).

In India area under rice cultivation is 44 million hectare and production of about 104 million tonnes with productivity of about 2.4 tonnes per hectare (2).

In Karnataka, rice is cultivated with an area of 13.43 lakh ha, production of 39.53 lakh tonnes and productivity of 3.09 tonnes per hectare (2).

The productivity of rice is highly affected by several biotic and abiotic factors. Rice crop is susceptible to many fungal, bacterial, viral and nematode diseases (3).

The most significant disease in rice is blast disease incited by Pyricularia oryzae as it is reported in more than 85 countries wherever rice is grown (4). Heavy yield losses have been reported in many rice growing countries viz., 75, 50 and 40 percent grain loss was occur in India (5), Philippines (6) and Nigeria (7).

The pathogen can cause damage up to $90 \%$ and sometime total crop loss under favourable conditions (8). The rice blast fungus can causes symptoms like leaf blast, nodal blast and neck or panicle blast. The most severe stage is neck blast (9). The usual practices followed for management of blast disease of rice includes use of resistant varieties, use of fungicides, application of fertilizers and irrigations $(10,11)$. Thus, the study was conducted for the Integrated Blast Disease Management of Paddy under field condition by using different management approaches.

\section{Materials and Methods}

An experiment was conducted during Kharif2017 and 2018 at Agricultural and Horticultural Research Station, Ponnampet. The susceptible variety Intan were sown on $11 / 07 / 2017,16 / 07 / 2018$ and transplanted on 18/08/2017, 20/08/2018 respectively in RCBD with 4 replications and 7 treatments. The spacing followed was $15 \mathrm{X} 15 \mathrm{~cm}$ and total plot size were10.12 $\mathrm{m}^{2}$ (Table 1 and Plate 1). The treatments were imposed in nursery and Main field as mentioned below.

Five hills were randomly selected from each plot and were tagged. The observations for leaf blast was recorded as PDI after first spray by using 0-9 scale given by IRRI (1996) and for the neck blast as percent neck blast incidence at second spray and at harvest, The leaf blast incidence was calculated by using formula given by (12).

\section{PDI}

$$
\begin{gathered}
\text { Sum of individual rating } \\
\begin{array}{c}
\text { Number of leaves assessed } \\
\text { x Maximum disease grade value }
\end{array}
\end{gathered}
$$

From the selected five hills randomly from each plot, the neck blast incident was calculated by using the formula given below.

Per cent neck blast incidence Infected panicles

$$
\text { Total number of panicles }
$$


Statistical analysis was carried out as per the procedure given by (13). The original means were converted into arc sine transformed values. The yield was recorded at harvest in all the treatments.

\section{Results and Discussion}

The pooled data results obtained indicates that, all the treatments recorded significantly reduced the pooled per cent leaf blast disease index and per cent neck blast disease incidence compared to untreated control. $\mathrm{T}_{6}$ : (N1: Incorporation of FYM @ $1 \mathrm{~kg} / \mathrm{m}^{2}$ in the nursery $+\mathrm{N} 2$ : Seed treatment with carbendazim $(2 \mathrm{~g} / \mathrm{kg})+\mathrm{N} 3$ : Apply DAP @ $108 \mathrm{~g} / 10 \mathrm{~m}^{2}$ nursery area before sowing the seeds + M5: Application of FYM during land preparation before transplanting $\left(@ 1 \mathrm{~kg} / \mathrm{m}^{2}\right)+$ Trichoderma formulation ( $2 \mathrm{~g} / \mathrm{kg}$ of FYM) + M6 : Cultural practices (cleaning of bunds i.e no weeds/infected straw on bunds and main field $)+$ M8: $75 \%$ RDF $(\mathrm{N}: \mathrm{P}: \mathrm{K}: \mathrm{Zn}-$ 67.50:56.25:56.25:15) + micronutrient solution @ $2 \mathrm{~g}$ or $2 \mathrm{ml}$ micronutrient product/litre of water, Micronutrient should be sprayed 15-20 days after transplanting. Micronutrient application should be repeated after 15 days after the first application + M9: One blanket application of granular insecticide (fipronil) at 15 DAT + M10: Need based application of following fungicides (tricyclazole 75 WP @ $0.6 \mathrm{~g} / \mathrm{l}$ ) based on the disease) and $\mathrm{T}_{5:}(\mathrm{N} 1$ : Incorporation of FYM @ $1 \mathrm{~kg} / \mathrm{m}^{2}$ in the nursery $+\mathrm{N} 2$ : Seed treatment with carbendazim $(2 \mathrm{~g} / \mathrm{kg})+\mathrm{N} 3$ : Apply DAP (a) $108 \mathrm{~g} / 10 \mathrm{~m} 2$ nursery area before sowing the seeds. Apply muriate of potash (MOP) @ $85 \mathrm{~g} / 10 \mathrm{~m}^{2}$ nursery area + M5: Application of FYM during land preparation before transplanting (@ $\left.1 \mathrm{~kg} / \mathrm{m}^{2}\right)+$ Trichoderma formulation ( $2 \mathrm{~g} / \mathrm{kg}$ of FYM) + M7:Apply 100\% RDF(N:P:K:Zn-90:75:75:20). Apply entire $\mathrm{P}$ and $\mathrm{K}$ and $1 / 2 \mathrm{~N}$ as basal dose and the remaining $1 / 2 \mathrm{~N}$ at maximum tillering stage. Apply $\mathrm{ZnSO}_{4}$ as basal dose + M9: One blanket application of granular insecticide (fipronil) at
15 DAT + M10: Need based application of following fungicides (tricyclazole 75 WP @ $0.6 \mathrm{~g} / \mathrm{l}$ ) based on the disease).

Both the treatments $\left(\mathrm{T}_{6} \& \mathrm{~T}_{5}\right)$ were on par with each other with least pooled leaf blast disease index of $20.15 \%$ and $22.28 \%$ and neck blast disease incidence of $15.73 \%$ and $17.93 \%$ respectively, when compared to control (59.94\% and $53.95 \%)$.

The maximum leaf blast per cent disease reduction over control (PDC) were observed in $\mathrm{T}_{6} \quad(66.38 \quad \mathrm{PDC})$ and $\mathrm{T}_{5}(62.83 \mathrm{PDC})$ followed byT $_{4}(59.56 \mathrm{PDC})$.

Similarly, the maximum neck blast per cent disease reduction over control (PDC) was observed in $\mathrm{T}_{6}\left(70.84\right.$ PDC) and $\mathrm{T}_{5}(66.77$ $\mathrm{PDC}$ ) followed by $\mathrm{T}_{4}(63.58 \mathrm{PDC})$.

Further, in the pooled data of yield observations, the highest pooled yield was recorded in $\mathrm{T}_{6}(4359.26 \mathrm{~kg} / \mathrm{ha})$ and $\mathrm{T}_{5}(4174.81$ $\mathrm{kg} / \mathrm{ha})$ followed by $\mathrm{T}_{4}(3959.26 \mathrm{~kg} / \mathrm{ha})$ when compared to control $(2745.18 \mathrm{~kg} / \mathrm{ha})$. The least pooled grain yield was observed in $\mathrm{T}_{2}$ $(3570.37 \mathrm{~kg} / \mathrm{ha})$ when compared to other treatments (Table 1 and Plate 1).

All the treatments investigated under field condition showed significant differences in blast disease reduction and grain yield.

The results obtained are also in agreement with the work of $(14,15)$ who also reported the complete inhibition of growth of Pyricularia oryzae in Trifloxystrobin $25 \%+$ Tebuconazole 50\% WG and Tricyclazole $75 \%$ WP as effective fungicides against Pyricularia oryzae. (16) who Singh and Singh (1988) reported weed hosts of $P$. oryzae Cav. were Leersia hexandra and Cyperus rotundus, while Brachiariamutica, Digitaria sp., Echinichloa sp. and Leersia hexandra reported by (17). (18) who reported Digitaria ciliaris and D. marginataact as collateral hosts for the 
blast fungus. Six bio-control agents' viz., Trichoderma harzianum, Trichoderma polysporum, Trichoderma pseudokoningii, Gliocladium virens, Paecilomyces variotii and
Paecilomyces lilacinus were used. Maximum mycelial inhibition of $M$. oryzae was provided by P. lilacinus followed by Trichoderma spp. (19).

Table.1 Treatment Details of Integrated Blast Disease Management of Paddy

\begin{tabular}{|c|c|}
\hline Sl. No. & Treatments Details \\
\hline $\mathrm{T}_{1}$ & $\begin{array}{l}\text { N1: Incorporation of FYM @ } 1 \mathrm{~kg} / \mathrm{m}^{2} \text { in the nursery }+ \\
\text { M5: Application of FYM during land preparation before transplanting }\left(@ 1 \mathrm{~kg} / \mathrm{m}^{2}\right)+\text { Trichoderma formulation }(2 \\
\text { g/kg of FYM })+ \\
\text { M11: Two times spray of neem based product @ } 3 \mathrm{ml} / \mathrm{lt} \text { at the time of tillering and booting stage }\end{array}$ \\
\hline $\mathbf{T}_{2}$ & $\begin{array}{l}\text { N3: Apply DAP @ } 108 \mathrm{~g} / 10 \mathrm{~m}^{2} \text { nursery area before sowing the seeds. }+ \\
\text { M4: Application of FYM during land preparation before transplanting }\left(\text { @ } 1 \mathrm{~kg} / \mathrm{m}^{2}\right)+ \\
\text { M7: Apply 100\% RDF (N:P:K:Zn-90:75:75:20). Apply entire P and } \mathrm{K} \text { and } 1 / 2 \mathrm{~N} \text { as basal dose and the remaining } \\
1 / 2 \mathrm{~N} \text { at maximum tillering stage. Apply ZnSO4 as basal dose. }\end{array}$ \\
\hline $\mathbf{T}_{3}$ & $\begin{array}{l}\text { N2: Seed treatment with carbendazim }(2 \mathrm{~g} / \mathrm{kg})+ \\
\text { N3: Apply DAP @ } 108 \mathrm{~g} / 10 \mathrm{~m} 2 \text { nursery area before sowing the seeds. }+ \\
\text { M7: Apply 100\% RDF (N:P:K:Zn-90:75:75:20). Apply entire P and K and } 1 / 2 \mathrm{~N} \text { as basal dose and the remaining } \\
\text { 1/2 N at maximum tillering stage. Apply ZnSO4 as basal dose }+ \\
\text { M9: One blanket application of granular insecticide (fipronil) at } 15 \mathrm{DAT}+ \\
\text { M10: Need based application of following fungicides (tricyclazole } 75 \mathrm{WP} @ 0.6 \mathrm{~g} / \mathrm{l}) \text { based on the disease. }\end{array}$ \\
\hline $\mathbf{T}_{4}$ & $\begin{array}{l}\text { N1: Incorporation of FYM @ } 1 \mathrm{~kg} / \mathrm{m}^{2} \text { in the nursery }+ \\
\text { N2: Seed treatment with carbendazim }(2 \mathrm{~g} / \mathrm{kg})+ \\
\text { N3: Apply DAP @ } 108 \mathrm{~g} / 10 \mathrm{~m}^{2} \text { nursery area before sowing the seeds. }+ \\
\text { M4: Application of FYM during land preparation before transplanting }\left(@ 1 \mathrm{~kg} / \mathrm{m}^{2}\right)+ \\
\text { M7: Apply 100\% RDF (N:P:K:Zn-90:75:75:20). Apply entire P and K and } 1 / 2 \mathrm{~N} \text { as basal dose and the remaining } \\
1 / 2 \mathrm{~N} \text { at maximum tillering stage. Apply ZnSO4 as basal dose }+\end{array}$ \\
\hline $\mathbf{T}_{5}$ & 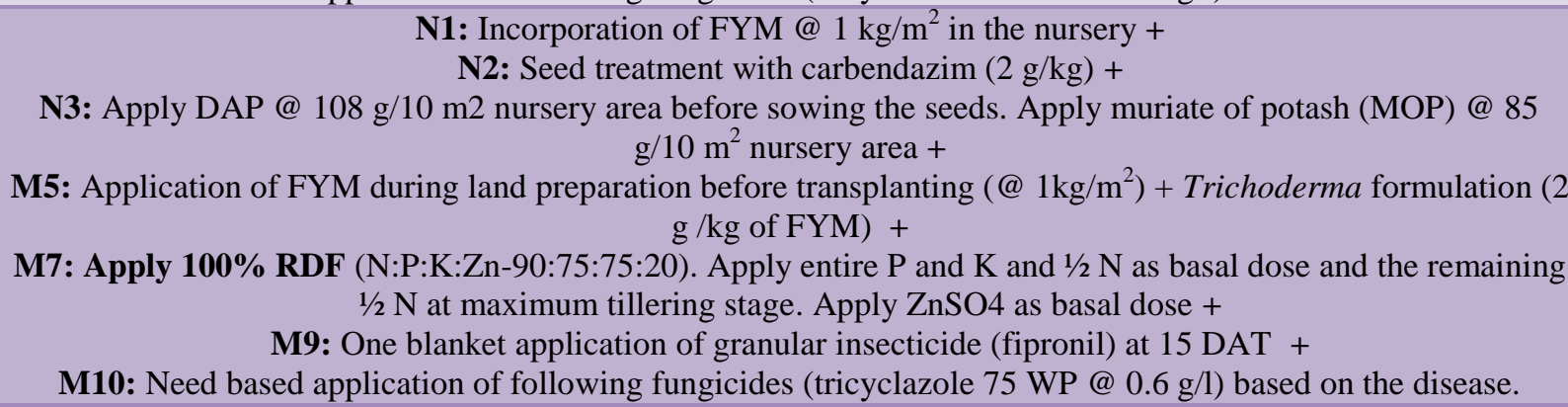 \\
\hline$T_{6}$ & $\begin{array}{c}\text { N1: Incorporation of FYM @ } 1 \mathrm{~kg} / \mathrm{m}^{2} \text { in the nursery }+ \\
\text { N2: Seed treatment with carbendazim }(2 \mathrm{~g} / \mathrm{kg})+ \\
\text { N3: Apply DAP @ } 108 \mathrm{~g} / 10 \mathrm{~m}^{2} \text { nursery area before sowing the seeds. }+ \\
\text { M5: Application of FYM during land preparation before transplanting }\left(@ 1 \mathrm{~kg} / \mathrm{m}^{2}\right)+\text { Trichoderma formulation (2 } \\
\mathrm{g} / \mathrm{kg} \text { of FYM })+ \\
\text { M6 : Cultural practices (cleaning of bunds i.e no weeds/infected straw on bunds } \\
\text { and main field) }+ \\
\text { M8: } 75 \% \text { RDF (N:P:K: Zn-67.50:56.25:56.25:15) + micronutrient solution @ } 2 \mathrm{~g} \text { or } 2 \mathrm{ml} \text { micronutrient } \\
\text { product/litre of water, Micronutrient should be sprayed } 15-20 \text { days after transplanting. Micronutrient application } \\
\text { should be repeated after 15 days after the first application + } \\
\text { M9: One blanket application of granular insecticide (fipronil) at } 15 \mathrm{DAT}+ \\
\text { M10: Need based application of following fungicides (tricyclazole } 75 \mathrm{WP} @ 0.6 \mathrm{~g} / \mathrm{l}) \text { based on the disease. }\end{array}$ \\
\hline $\mathbf{T}_{7}$ & Control \\
\hline
\end{tabular}


Table.2 Integrated blast disease management of paddy in hill zone of Karnataka, during 2017 and 2018

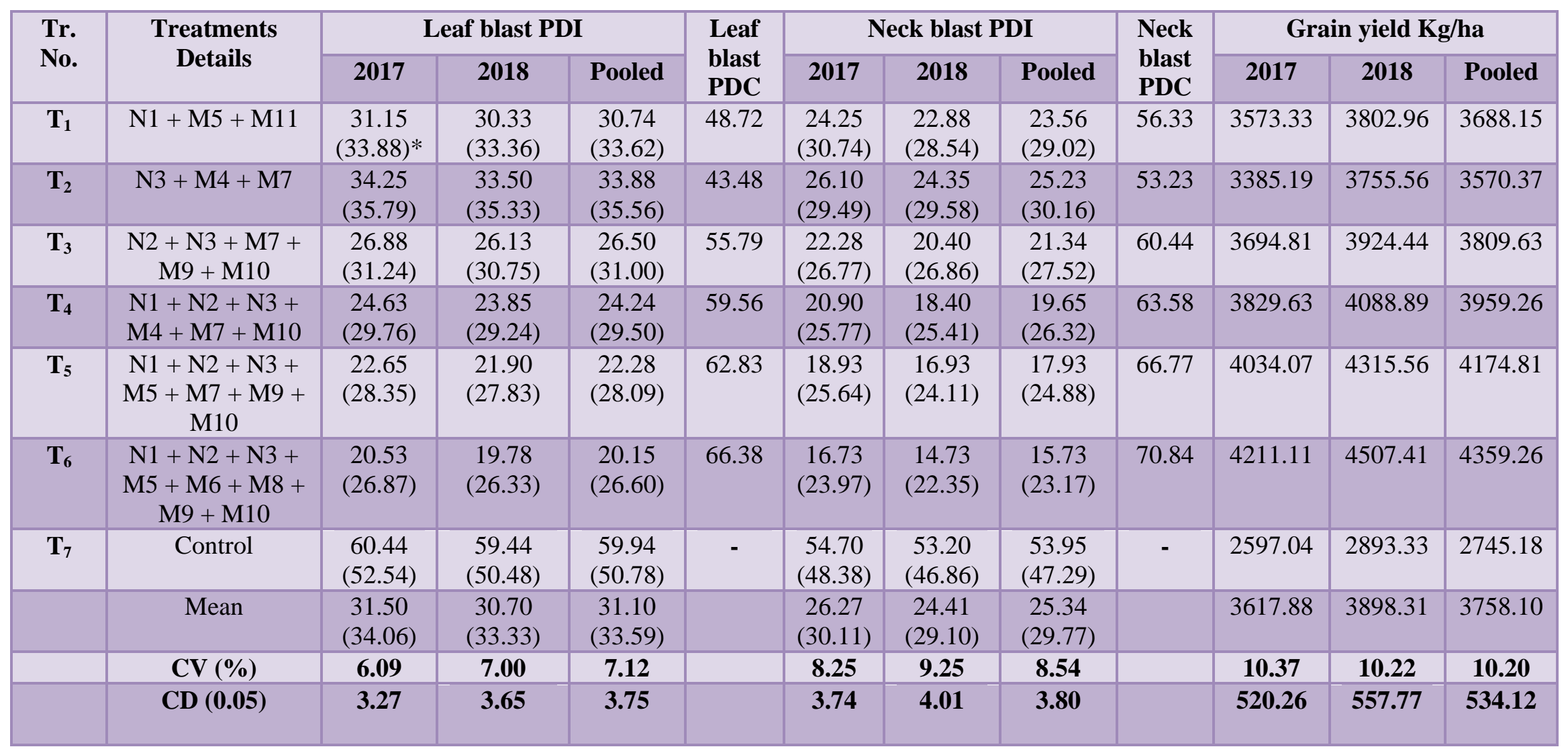

*figures in parenthesis are arc sine transformed values. PDI- Per cent Disease Index. PDC - Per cent Disease reduction over Control. 
Fig.1 Field view of Integrated Blast Disease Management of Paddy in Hill Zone of Karnataka

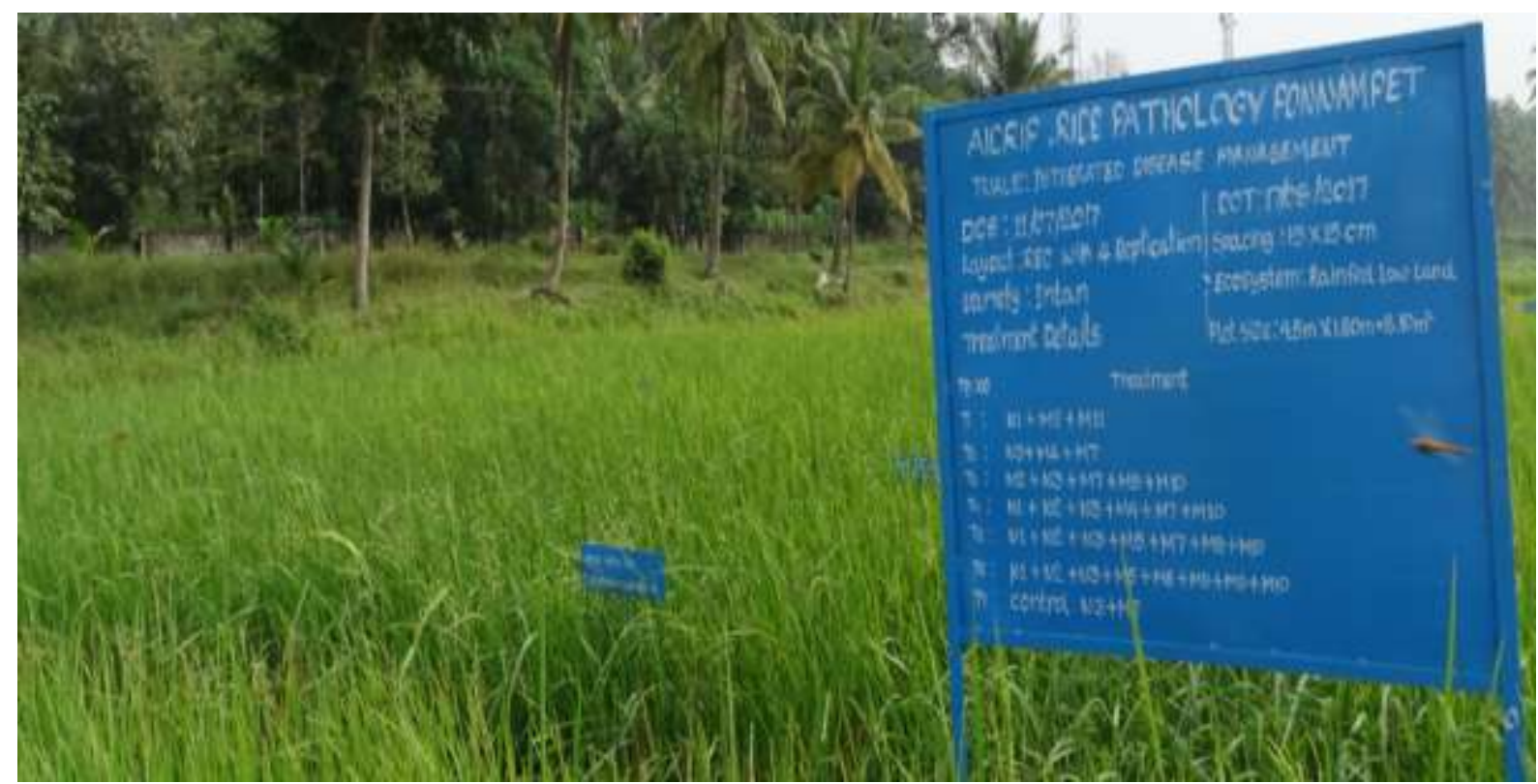

\section{References}

Tony CK. Techniques for organic paddy cultivation. Indigenous Agriculture News. 2005; 4:1-4.

Anonymous. Statistical database. 2017; http://www.fao.org.

Hollier CA, Groth DE, Rush MC, Webster AK. Common Names of Plant Diseases.The American Phytopathological Society, St. Paul, MN, 1984.

Gilbert MJ, Soanes DM, Talbot NJ. Functional Genomic Analysis of the Rice Blast Fungus Magnaporthegrisea. Appl. Mycol. and Biotechnol. 2004; 4:331-352.

Padmanabhan SY. Estimating losses from rice blast in India. Pages 203-221 in the rice blast disease. Proceeding of symposium at IRRI, 1965.

Ou SH. Rice Diseases, CAB International Mycological, Institute Kew, Survey, UK. Johan Hopkins Press, Baltinoie, Maryland. 1985, 203-221.

Awodera VA, Esuruoso OF. Reduction in grain yield of two rice varieties infected by rice blast disease in Nigeria. Nigerian Agric J. 1975; 11:170-173.

Samira S, Afifa M, Amina D, Allal D. In vivo effect of fungicides on the development of Pyricularia grisea and Heliminthosporiumoryzae.Phytopathol. Mediterranian.2002; 41:235-246.

Bonman JM, Estrada BA, Banding JM. Leaf and neck blast resistance in tropical lowland rice cultivars. Plant Dis. 1989; 73:388-390.

Georgopoulos SG, Ziogas BN. Principles and methods for control of plant diseases, Athens. 1992, 236.

Naidu VD, Reddy GV. Control of blast (BI) in main field and nursery with some new fungicides. R.P.P. 1989; 69:209.

Wheeler BEJ. An Introduction to Plant Diseases. John Wiley and Sons, Ltd. London.1969, 301.

Panse VG, Sukathme PV. Statistical methods for agricultural workers. ICAR, New Delhi. 1967, 145-155.

Neelakanth, Sidde Gowda DK, Chethana BS, Parasappa HH. In vitro and In vivo Evaluation of Fungicides against 
Pyricularia oryzae Causing Blast of Rice. Int. J. Pure App. Biosci. 2017; 5(3):259-263.

15.Wasimfiroz RM, Hosagoudar GN, Narayanaswamy $\mathrm{H}$ and Balanagouda Patil. Evaluation of fungicides, bioagents and plant extracts against Pyricularia oryzae. International Journal of Chemical Studies 2018; 6(2): 1875-1879

SinghN Iand Singh K U. Unrecorded weed hosts for rice blast pathogen Pyricularia oryzae Cav. in India. IRRN, 1988, 13(5): 35.

17*Kim LV, Len, L, Hoang, V T, Thuy T,
Hoa, L Hand HOAI, G. Host range of Pyricularia oryzae and Thanatephorus cucumeris in the Vietnamese Mekong Delta. IRRN., 1981, 6(4): 10.

Prasad S M, Kumar S and Prasad L M S. Weed hosts of rice blast fungus in Meghalaya, India. Oryza., 1998, 35: 384-385.

Hajano J, Mubeen Lodhi A, Mumtaz A, Pathan M, Ali K and Serwar, S. G., 2012, in-vitro evaluation of fungicides, plant extracts and bio-control agents against rice blast pathogen Magnaporthe oryzae couch., Pak. J. Bot., 44(5): 1775-1778.

\section{How to cite this article:}

Hosagoudar, G. N. 2019. Integrated Blast Disease Management of Paddy in Hill Zone of Karnataka, India. Int.J.Curr.Microbiol.App.Sci. 8(10): 1766-1772. doi: https://doi.org/10.20546/ijcmas.2019.810.205 